\title{
Revisiting Humanae Vitae, Fifty Years Later*
}

On October 14, 2018 the Catholic Church celebrated the canonization of Blessed Pope Paul VI. Although Paul VI always steered his way wisely through the straits between the liberal and the conservative groups within the Church; even though his influence on the social and political teaching of the Church was invaluable and positive; indeed, despite his leading the Second Vatican Council to its end and laying the foundations for it to be implemented; it is truly ironic that the Church remembers this Holy Father mostly for his last encyclical: an encyclical written ten years before his death, and fifty years before his canonization.

Humanae vitae, ${ }^{1}$ known mostly for its teaching on birth control, remains the most controversial encyclical in the recent history of the Church. Considered as the most important Church document for those who adhere

* This paper was presented as the Inaugural Lecture of the 2018-2019 Pastoral Programme of the Cana Movement on September 28, 2018, at the Catholic Institute, Floriana, Malta. Heartfelt thanks to Ms. Christine Rossi who translated into English the original version in Maltese.

1 Pope Paul VI, Encyclical Humanae Vitae: On the Regulation of Birth, July 25, 1968, https://w2.vatican.va/content/paul-vi/en/encyclicals/documents/hf_p-vi_enc_25071968_ humanae-vitae.html (28.12.2018). 
to the 'conservative' voice of the Church, but at the same time, an encyclical which has been next to ridiculed by those who consider themselves liberal, Humanae Vitae certainly sparked off the vociferous war in post-Conciliar moral theology, which is still present today. What is also true is that the teachings of this encyclical are mostly forgotten among the people of Godor if not exactly forgotten, ignored or misunderstood. For many a married couple, this encyclical is a portrayal of how disconnected 'the Church' is from reality; how it misunderstands their situation, or how it ignores the complexity of the life they live.

We certainly cannot ignore two major developments since the writing of the encyclical: an internal theological development and an external scientific development. The internal development started with St. John Paul II, who, during his long papacy, showed a great commitment to provide a worthy theo-anthropological background to this encyclical. What is today known as "the theology of the body" gives great importance to the bodily dimension of the human, created as woman and man, with a distinct but complementary dignity which finds its fulfilment in the life of marriage. At the same time, we also know that in the past fifty years, procreative technology has developed in leaps and bounds. Ten years after Humanae Vitae, we witnessed the first baby through IVF (in-vitro fertilization) and today, in many countries, we find a prosperous industry of assisted reproduction. Ironically, the 'pill' itself, which the encyclical responds to as one of the main signs of its times, as well as other means of hormone-based artificial contraception, has become more controversial because of its negative effects on the health of the woman. Nevertheless, the 'culture of choice' which conceived of the 'pill'-or more accurately still, the culture which insists that a woman has the right to refuse child-bearing-has continued to thrive and set deeper roots. In the light of all these social, political, cultural and even scientific changes, Humanae Vitae deserves to be read and studied afresh fifty years on. We need to reread this encyclical with new eyes and without prejudices to understand how it speaks to our contemporary reality. This is what this paper aims to present.

Pope Paul VI himself identified three aspects of the rapid social, political and cultural changes which, in his time, had already led the Church to reflect on the artificial methods of contraception. In para. 2 of Humanae Vitae he writes: "The changes that have taken place are of considerable importance and varied in nature: 
In the first place there is the rapid increase in population which has made many fear that world population is going to grow faster than available resources, with the consequence that many families and developing countries would be faced with greater hardships. This can easily induce public authorities to be tempted to take even harsher measures to avert this danger. There is also the fact that not only working and housing conditions but the greater demands made both in the economic and educational field pose a living situation in which it is frequently difficult these days to provide properly for a large family.

Also noteworthy is a new understanding of the dignity of woman and her place in society, of the value of conjugal love in marriage and the relationship of conjugal acts to this love.

But the most remarkable development of all is to be seen in man's stupendous progress in the domination and rational organization of the forces of nature to the point that he is endeavoring to extend this control over every aspect of his own life-over his body, over his mind and emotions, over his social life, and even over the laws that regulate the transmission of life."

This paragraph shows, first and foremost, that Pope Paul VI presents the problem of artificial methods of contraception as a political and economic one. In other words, he asks: should the state interfere in the choices that a couple makes about how many children (if any at all) are to be conceived? Moreover, there is another more complex but pragmatic question linked to this issue: if the birth rate is also a concern of the state and not only of the couples themselves, what legitimate measures can, or possibly should, be taken by the state, for couples to raise their children in a dignified manner? These are important questions, but the most salient point which emerges is that by framing this issue within a political framework, and thus within a wider perspective, Humanae Vitae made it clear that the conception and birth of children is not just an individual or private ethical choice (which in the Church is often expressed as sexual ethics). Rather, in its essence, it is a crucial contribution to the social teaching of the Church that, above all, defends human dignity in the wider context that is intrinsically 'social' and, thus political. This is the most important aspect of the anthropology of Pope 
Paul VI, an aspect which he had already expressed strongly in his principal encyclical Populorum Progressio. ${ }^{2}$

This traditional and comprehensive anthropology, which considers the human being as a member of society, as Pope Paul VI points out in his second point above, on the distinct role of women in society, also implies that, in its essence, Christian anthropology is relational. Thus, it is an anthropology that asks what it means to be a human 'person', with one's particular characteristics. Amongst these fundamental characteristics that express the individuality of the person, there is obviously gender, that which makes one a woman or a man. This determines how a person forms and lives one's relationships, which ultimately, are not only political or within a wider community of persons, but also intimate, and therefore the most essential foundation of society, in the family, built on marriage which gives new life to children.

As Pope Paul VI clearly shows, in Christian anthropology, the sociopolitical and intimate-familial aspects are neither in contradiction, nor can they be considered in a separate manner. Rather, they are an expression of the same 'personalism' which, while always central to the tradition - from the Fathers, to St. Thomas Aquinas - takes a radical expression in John Paul II, where it grounds the moral theological reform which was called for in Vatican Council II. ${ }^{3}$ Therefore, the first part of this reflection will focus on the theological anthropology of Humanae Vitae and how this continues to develop in the Church's thought, especially in the light of the moral theological reform which took an important turn with John Paul II.

The second part of the paper, however, will focus more on the third 'sign of the time' that Pope Paul VI contemplated in Humanae Vitae, that is, "man's stupendous progress in the domination and rational organization of the forces of nature to the point that he is endeavoring to extend this control over every aspect of his own life - over his body, over his mind and emotions, over his social life, and even over the laws that regulate the transmission of

\footnotetext{
2 Pope Paul VI, Encyclical Populorum Progressio: On the Development of Peoples, March 26, 1967, http://w2.vatican.va/content/paul-vi/en/encyclicals/documents/hf_p-vi_ enc_26031967_populorum.html (28.12.2018).

3 See: Nadia Delicata, The Renewal of Moral Theology: From Confessing Sins to Forming Christians in the World, in: The Quest for Authenticity and Human Dignity: A Festschrift in Honour of Professor George Grima on his 70th birthday, eds. H. Scerri, E. Agius, Valletta, Malta 2015, Foundation for Theological Studies, pp. 135-153.
} 
life." This is the most crucial point, since more than ever before, we witness how Christian anthropology faces new and difficult challenges in light of developments in technology. Humanae Vitae was truly prophetic when it reflected on artificial methods of birth control and urged "man not to betray his personal responsibilities by putting all his faith in technical expedients." I will be developing this point further in light of Pope Francis' encyclical Laudato Si, which addresses the challenges of a culture which has become 'technocratic'.

It is also in this light that I will develop the third point of this paper, which is the most pressing for the Church's reflection. In para. 19-22, Pope Paul VI issues "Pastoral Directives" that must be considered carefully. In these past fifty years, the tendency to reduce the teachings of Humanae Vitae to the conclusion that "the Church is against artificial means of birth control" has done great damage to the Church herself. Married couples, committed in their ministry in the domestic Church, are the heart of the Church and yet, we have fostered a culture whereby Christian morality has been equated with a list of laws that one should follow blindly. This attitude had negative effects not only directly - in that many couples simply ignored the challenge posed to them by this encyclical - but even indirectly, where all the moral teachings of the Church, today, are reduced to a mere opinion, one amongst many others, without the commitment to seek to struggle to understand the reasoning underlying that particular moral teaching. However, as we shall see, Pope Paul VI did not simply present "a law" which one chooses to obey. In the light of the long tradition of the moral teaching of the Church, he presents a pedagogy of marriage, which Pope John Paul II, and more recently, Pope Francis, continued to build upon. Thus, my third point will be a pastoral reflection on how the teaching of Humanae Vitae can be lived to the full in light of the principle of gradualness which John Paul II presented in his Apostolic Exhortation Familiaris Consortio, ${ }^{5}$ and which is more fully developed in Pope Francis' Apostolic Exhortation Amoris Laetitia. ${ }^{6}$

\footnotetext{
$4 \quad$ Humanae Vitae, 18.

5 Pope John Paul II, Apostolic Exhortation Familiaris Consortio: On the Christian Family in the Modern World, November 22, 1981, http://w2.vatican.va/content/john-paulii/en/apost_exhortations/documents/hf_jp-ii_exh_19811122_familiaris-consortio.html, 34 (28.12.2018).

6 Pope Francis, Apostolic Exhortation Amoris Laetitia: On Love in the Family, March 19, 2016, http://w2.vatican.va/content/dam/francesco/pdf/apost_exhortations/documents/ papa-francesco_esortazione-ap_20160319_amoris-laetitia_en.pdf, 293-295 (28.12.2018).
} 


\section{The theological anthropology of Humanae Vitae}

The core teaching of Humanae Vitae is the doctrinal principles that Pope Paul VI develops in para. 7 to 13. As he stated in the well-known para. 14: "We base Our words on the first principles of a human and Christian doctrine of marriage, when We are obliged once more to declare... [and here he makes a list of prohibitions which we are all familiar with]:

- that the direct interruption of the generative process already begun

- above all, all direct abortion, even for therapeutic reasons,

- are to be absolutely excluded as lawful means of regulating the number of children.

Equally to be condemned, as the magisterium of the Church has affirmed on many occasions, is direct sterilization, whether of the man or of the woman, whether permanent or temporary.

Similarly excluded is any action which either before, at the moment of, or after sexual intercourse, is specifically intended to prevent procreationwhether as an end or as a means."

What are these "first principles" of human and Christian marriage, expressed in the most definite of terms and in the light of faith - and therefore which, one can also describe as final?

Like all models of theological anthropology, Pope Paul VI's is also an application of the foundational revelation of imago Dei. This teaching, of the human being created in the image and likeness of God, is about the intrinsic essence of the human being, that is, our being in "the image of God", but also what this implies for the purpose of the human being, the call of becoming in God's "likeness". Therefore, as the tradition of the Church has always maintained, the human being is not only created from God, but also to find their fulfilment in God. This principle is most evident when we study Scripture and truly understand God's revelation to us: that is, who God revealed himself to be, in his essence, as revealed in the world through his Son Jesus Christ. As St. John says in his First Letter, and as he clearly portrays in the Fourth Gospel when he says that "God so loved the world that he gave his only Son" (Jn 3:6) - this Son who loved those so dear to him that he died on the cross! - "God is love" (I Jn 4:8). In his essence, God is spirit and God is love. And the human, created in body and soul "in the image of God", is also a spiritual being who desires to love, and 
as such, man and woman find their fulfillment in God alone who is love. Therefore, all forms of love that a human expresses towards another person are a participation in the love of God; in the love that is God in Godself. And if the person is both body and soul, there is no greater human love than the expression of mutual total self-giving love in body and soul. Like God in Godself: Father, Son and Holy Spirit, the One God in Three Persons in a communion of total and mutual self-giving; so too the ideal of Christian marriage: a mutual total love which makes them one body and one soul. Moreover, as God in Godself, expresses God's infinite love as Creator, so too the total mutual self-giving between man and woman gives life, and indeed, bears its fruit as children. As Pope Paul VI says in para. 8: "Married love particularly reveals its true nature and nobility when we realize that it takes its origin from God, who "is love," the Father "from whom every family in heaven and on earth is named." Marriage, then, is far from being the effect of chance or the result of the blind evolution of natural forces. It is in reality the wise and provident institution of God the Creator, whose purpose was to effect in man His loving design. As a consequence, husband and wife, through that mutual gift of themselves, which is specific and exclusive to them alone, develop that union of two persons in which they perfect one another, cooperating with God in the generation and rearing of new lives. The marriage of those who have been baptized is, in addition, invested with the dignity of a sacramental sign of grace, for it represents the union of Christ and His Church."

It is in this context, of mutual, exclusive, life-long love between two unique, and thus different persons, including in that fundamental diversity of humankind that is gender, that is their being man and woman, that sexuality takes its theological meaning. Adam and Eve, together, mirror how 'the human being', the whole of humanity with all the differences found amongst persons, is created by God, in the image of the Trinity, so as to find individual personal fulfillment in communion, in society. In every marriage there is a celebration of the distinctiveness that separates us most clearly in our humanity. Most fundamentally, it is not our personalities or superficial physical characteristics that make us different, but that primordial difference between man and woman. Through the most complete self-gift (and risk!) which bears fruit, man and woman together, in mutuality and complementarity, must also build society in all its rich diversity. Cultural 
and individual differences make us all unique persons, each with our personal story. But the difference in body and soul between the woman and the man presents the greatest personal challenge to find one's 'self' in 'the other'... precisely because the chasm-and complementarity-between genders is so deep. No wonder that in marriage we find the greatest relational difficulties, but also the potential for the greatest relational satisfaction. It is indeed because we are persons seeking 'the other' who fulfills the 'Self', that the difference between woman and man is 'complementary' - and not, in the words of Bernard Lonergan, 'contradictory' or even 'genetic', that is a developmental difference as that between the parents and child.

Likewise, human nature that fulfils itself in the mutual self-giving between man and woman, not only in the soul - as in friends or soul mates but in both body and soul, demands that this gift is truly all-encompassing, "my whole life"; truly generous, "all that I am"; truly an expression of the true 'me' and of the true 'thou'; and so is exclusively between us. This, therefore implies that it needs to be a completely free and voluntary self-gift; a gift whereby our shared life truly becomes one life, a new reality, the birth of a family and a domestic church. This obviously implies that in marriage, man and woman do not just become one 'household' on an economic and social level, but also in their physical body, and so through the particular fertility of the woman and the man. An essential part of the true gift of the 'Self' to the true 'Thou' is that together, in the expression of our love through the gift of body and soul, we become a tool in the hands of God for the creation of our children. That is why Pope Paul VI writes in para. 9: "This love is fecund. It is not confined wholly to the loving interchange of husband and wife; it also contrives to go beyond this to bring new life into being. "Marriage and conjugal love are by their nature ordained toward the procreation and education of children. Children are really the supreme gift of marriage and contribute in the highest degree to their parents' welfare."'

The intrinsic bond between marriage and the upbringing of children is the personal transformation of the couple who are no longer merely 'woman' and 'man', but become 'mother' and 'father'. It is motherhood and fatherhood that are the most essential relationships for society, since society will only exist if it has future generations who are formed, and therefore educated, by those who have helped them grow in their relational nature, that always seeks love. 
Thus, the mission of parents as educators is both important and difficult. The new cultural realities in which we live present novel and complex challenges. It is not easy for us, in the contemporary world, to know what it takes to educate our children; it is not so clear to understand how best to be parents in bringing up our children. The notion of parenthood and the duties of parents are changing: if we previously had a clear understanding of the roles of father and mother - a public role and a domestic role respectively - today, not only the distinction between what is public and domestic no longer exists, but both are accountable in new emergent ways in a milieu that is liquid and fragile, where the social, political and cultural expectations are in constant flux. In this context, to have children implies greater risk and resilience that requires much wisdom and responsibility. This greater need for 'responsibility' also becomes harder to concretize when we open up our horizons and consider the civil and global role of the parent. That a couple is open to life is always a personal decision, but that has social and political repercussions (and thus responsibilities). No couple should take such decisions without due consideration and prudence.

This means that, in marriage, the way in which the couple, in every stage of its life, gives oneself to one another implies their responsibility, not only towards each other, but also towards the children, their children's children, and towards society and future generations. Generous self-giving is not only a temporary gift; it opens us up to become and welcome gratuitous self-giving not only in the act of marriage, but also in the motherhood and fatherhood that it makes implicit. So we see that, as love and mutual selfgiving between the couple become more conscious and considered, the spirit of openness to others grows. Marriage does not only bear fruit in biological children, but in every act of generosity through which the couple opens up their home, their family, their love to share it with others. The spirit of motherhood and fatherhood is shown through every generous act of persons who grow together in a spirit of giving.

It is in this light that artificial contraception needs to be understood: in the context of a wider meaning of Christian marriage as a participation in the creative love of God that always yields new life abundantly; it is because marriage transforms the couple itself into an instrument of the generous love of God. The moral problem surrounding artificial means of contraception is not linked to the legitimate and important decision, which 
every couple should wisely make throughout their fertile life, of when and how many children to bear. The problem of contraception is that it separates the procreative act from the unitive act between the couple; it is precisely because it denies the role of God who, through the whole mutual gift of the couple, sanctifies it with love which gives life, even - but not only - through the gift of children. Contraception implies the message for the couple that the potential to procreate is distinct and different from the love between them. But the gift of the person, which is not totally present or available, is not a perfect gift; rather, it is a fragmented gift that disintegrates the person himself or herself. Artificial means of contraception communicate the message that the couple are not ready to give one's all to each other, but are only ready to offer some aspects of each other - which in the act of marriage, implies disassociating the physical pleasure from the whole potential for the body to be generous and bear fruit. It is for this reason that Pope Paul VI understood that how we consider artificial contraception is not only a matter of when one can use them or when one cannot, but it is the "contraceptive mentality" itself that goes against the total mutual gift in Christian marriage. As Pope Paul VI clearly explains: "Neither the Church nor her doctrine is inconsistent when she considers it lawful for married people to take advantage of the infertile period but condemns as always unlawful the use of means which directly prevent conception, even when the reasons given for the later practice may appear to be upright and serious. In reality, these two cases are completely different. In the former the married couple rightly use a faculty provided them by nature. In the later they obstruct the natural development of the generative process. It cannot be denied that in each case the married couple, for acceptable reasons, are both perfectly clear in their intention to avoid children and wish to make sure that none will result. But it is equally true that it is exclusively in the former case that husband and wife are ready to abstain from intercourse during the fertile period as often as for reasonable motives the birth of another child is not desirable. And when the infertile period recurs, they use their married intimacy to express their mutual love and safeguard their fidelity toward one another. In doing this they certainly give proof of a true and authentic love."

The "contraceptive mentality" directly targets the "truthfulness" of love as a conscious and free gift without restrictions. In order to understand

\footnotetext{
$7 \quad$ Humanae Vitae, 16.
} 
the danger of this mentality within a Christian marriage we also need to understand how, in itself, it creates a new narrative about the meaning of the bond in marriage and of motherhood and fatherhood, when these become not only a result of a free and rational decision made out of love, but they become a "technical method".

\section{The contraceptive mentality linked with technology}

In his encyclical Laudato Si, Pope Francis dedicates a whole chapter to what he identifies as "the fundamental problem" in contemporary culture: "it is the way that humanity has taken up technology and its development according to an undifferentiated and one-dimensional paradigm. This paradigm exalts the concept of a subject who, using logical and rational procedures, progressively approaches and gains control over an external object. This subject makes every effort to establish the scientific and experimental method, which in itself is already a technique of possession, mastery and transformation. It is as if the subject were to find itself in the presence of something formless, completely open to manipulation. Men and women have constantly intervened in nature, but for a long time this meant being in tune with and respecting the possibilities offered by the things themselves. It was a matter of receiving what nature itself allowed, as if from its own hand. Now, by contrast, we are the ones to lay our hands on things, attempting to extract everything possible from them while frequently ignoring or forgetting the reality in front of us. Human beings and material objects no longer extend a friendly hand to one another; the relationship has become confrontational. This has made it easy to accept the idea of infinite or unlimited growth, which proves so attractive to economists, financiers and experts in technology. It is based on the lie that there is an infinite supply of the earth's goods, and this leads to the planet being squeezed dry beyond every limit. It is the false notion that an infinite quantity of energy and resources are available, that it is possible to renew them quickly, and that the negative effects of the exploitation of the natural order can be easily absorbed".

8 Pope Francis, Encyclical Laudato Si: On Care of Our Common Home, May 24, 2015, http://w2.vatican.va/content/francesco/en/encyclicals/documents/papa-francesco_2015 0524_enciclica-laudato-si.html, 106 (28.12.2018). 
In this paragraph, in the spirit of the encyclical Laudato Si, which deals most specifically with the human responsibility to care for the Earth, Pope Francis is speaking of how the "technological" mentality reduces all material aspects in our environment to simple 'matter' that can be 'controlled', and therefore 'exploited' more than 'appreciated' in its essence. It follows that artificial means of contraception (including contraceptive 'natural' methods) are not unlike any other technological means, precisely because they also reflect the technical mentality of reducing all that is 'material' to 'a thing' (and therefore purely an 'object') which can be 'used' or 'manipulated' according to one's wishes. ${ }^{9}$

In themselves, technologies that regularise the birth of children imply that the human body, gametes, and even the embryo after conception, are only 'matter' which can be used (or discarded) in order to achieve the result desired. Do you wish to enjoy a sexual relationship with your partner without any fear of conceiving? Then contraceptives can halt ovulation, or prevent the sperm from fertilizing the woman's egg. Would you like to conceive biological children despite great physical difficulties (or impossibilities)? You can create an embryo according to your particular desires and it can grow in a womb of your choice. In the technocratic mentality, becoming a parent is no longer the fruit of a mutual gift (while one continues to rely on considerable help from technology, in such instances as when medicine saves the life of the mother and child in medical emergencies) but it becomes a form of technical manipulation of human biology. The miracle of the conception of children, and the transformation of the couple who become parents, is also affected by the technocratic mentality. And the most serious problem of this mentality is, indeed, that we have denied ourselves the freedom to give ourselves to each other totally.

As Pope Francis says in Laudato Si, para. 108: "The idea of promoting a different cultural paradigm and employing technology as a mere instrument is nowadays inconceivable. The technological paradigm has become so dominant that it would be difficult to do without its resources and even more difficult to utilize them without being dominated by their internal logic. It has become countercultural to choose a lifestyle whose goals are even partly independent of technology, of its costs and its power to globalize

9 See N. Delicata, The Family and the Dominant Technocratic Paradigm: Challenges in a Digital Culture, in: Strengthening Families, eds. J. Stala, J. Garmaz, Krakow 2016: Pontifical University of John Paul II in Krakow Press, pp. 223-250. 
and make us all the same. Technology tends to absorb everything into its ironclad logic, and those who are surrounded with technology "know full well that it moves forward in the final analysis neither for profit nor for the well-being of the human race", that "in the most radical sense of the term power is its motive - a lordship over all". As a result, "man seizes hold of the naked elements of both nature and human nature". Our capacity to make decisions, a more genuine freedom and the space for each one's alternative creativity are diminished."

Pope Paul VI in Humanae Vitae had already foreseen the effects of this technical mentality of contraception. Fifty years ago, he prepared the Church that: "It is to be anticipated that perhaps not everyone will easily accept this particular teaching [the Church's teaching on contraception]. There is too much clamorous outcry against the voice of the Church, and this is intensified by modern means of communication. But it comes as no surprise to the Church that she, no less than her divine Founder, is destined to be a "sign of contradiction." ${ }^{10}$ Our culture, in fact, presents contraceptives not only as attractive, but even as a duty. A man in particular is responsible by practicing "safe sex". But a woman needs to be especially responsible; not so much (as in the past) to control her sexual expression, but to 'sterilise' her fertility. In a culture where contraceptives separate "the inseparable connection, established by God, which man on his own initiative may not break, between the unitive significance and the procreative significance which are both inherent to the marriage act" ${ }^{\prime 1}$, the children have taken on the uncertain status of "those we desire and choose" - which means, therefore, that they also become those "we do not desire and we do not choose". In this context, the fruit of the sexuality of the woman is portrayed as only belonging in her body, and thus her fertility has taken on a new ambiguity. The woman is no longer the temptation for the man; but she whom through her body chooses or denies children.

This is why, therefore, Pope Paul VI also warns that "a man who grows accustomed to the use of contraceptive methods may forget the reverence due to a woman, and, disregarding her physical and emotional equilibrium, reduces her to being a mere instrument for the satisfaction of his own desires, no longer considering her as his partner whom he should surround with care

\footnotetext{
10 Humanae Vitae, 18.

11 Humanae Vitae, 12.
} 
and affection." ${ }^{12}$ The new role of the woman in society has not necessarily given a new freedom, but possibly a new slavery - the control of her own fertility. If the woman is not free to express her nature and potential, neither can the man be free to be a worthy companion for her. The 'technocratic' culture poses a new challenge to Christian marriage that demands a pastoral sensitivity. In particular this demands by the couple ongoing discernment about how they are to express, in the most wholesome way possible, their vocation of motherhood and fatherhood, even in a wider sense.

\section{Humanae Vitae in pastoral work}

Pope Paul VI, undoubtedly recognised that what the Church is calling for from married couples in this technocratic culture, is nothing short of heroic. In para. 20 , he tersely writes: "The teaching of the Church regarding the proper regulation of birth is a promulgation of the law of God Himself. And yet there is no doubt that to many it will appear not merely difficult but even impossible to observe. Now it is true that like all good things which are outstanding for their nobility and for the benefits which they confer on men, so this law demands from individual men and women, from families and from human society, a resolute purpose and great endurance. Indeed it cannot be observed unless God comes to their help with the grace by which the goodwill of men is sustained and strengthened. But to those who consider this matter diligently it will indeed be evident that this endurance enhances man's dignity and confers benefits on human society."

Pope Francis expresses the same thoughts, nearly fifty years later, when in his apostolic exhortation on Christian marriage itself, Amoris Laetitia, he stressed the importance of the accompaniment of every couple - married or not, wounded or not - so that through ongoing discernment they may grow closer toward the Christian ideal... even when the context in which one is living presents great challenges that are impossible to overcome. Pope Francis builds this ongoing pedagogy towards the ideal of Christian marriage using the "the law of gradualness" of Pope John Paul II. ${ }^{13} \mathrm{He}$ writes: "Along these lines, Saint John Paul II proposed the so-called "law of gradualness"

\footnotetext{
12 Humanae Vitae, 17.

13 Familiaris Consortio, 34.
} 
in the knowledge that the human being "knows, loves and accomplishes moral good by different stages of growth". This is not a "gradualness of law" but rather a gradualness in the prudential exercise of free acts on the part of subjects who are not in a position to understand, appreciate, or fully carry out the objective demands of the law. For the law is itself a gift of God which points out the way, a gift for everyone without exception; it can be followed with the help of grace, even though each human being "advances gradually with the progressive integration of the gifts of God and the demands of God's definitive and absolute love in his or her entire personal and social life." ${ }^{14}$

Moreover, Pope Francis builds on principles that are close to his heart and crucial to his pontificate: that "time is greater than space," 15 and so, that time opens us up to eternity even when the reality we live in the present is extremely challenging.

The expression of sexuality in marriage is not just a biological act or even a sensual need: it is a symbolic act, and many a time, is the most obvious thermometer with which to gauge the general state of health of the marriage. In their sexual expression the couple communicates much more than total mutual love: indeed, many a time a couple communicates its weaknesses more than its perfect love. However, in the pedagogical spirit of discernment, I think that it is important that we also consider the sexual aspect of a couple in a holistic manner, and so, we also consider all the ways in which the couple can grow in order to reach fulfilment in the sexual act, meant to be unitive and procreative (in the wider sense of the word), in a most complete way. The central guiding principle for couples, should, I think, be that whilst never abandoning the ideal, in every moment, the couple should discern not only between what is good and what is bad, but all the good - no matter how small it may be - that can be accomplished in that moment and that which they are obliged to do in that moment.

To quote from para. 305-306 of Amoris Laetitia: "Because of forms of conditioning and mitigating factors, it is possible that in an objective situation of sin - which may not be subjectively culpable, or fully such - a person can be living in God's grace, can love and can also grow in the life of grace and

\footnotetext{
$14 \quad$ Amoris Laetitia, 295.

15 Pope Francis, Apostolic Exhortation Evangelii Gaudium: On the Proclamation of the Gospel in Today's World, November 24, 2013, http://w2.vatican.va/content/francesco/en/ apost_exhortations/documents/papa-francesco_esortazione-ap_20131124_evangelii-gaudium.html, 222-225 (28.12.2018).
} 
charity, while receiving the Church's help to this end. Discernment must help to find possible ways of responding to God and growing in the midst of limits. By thinking that everything is black and white, we sometimes close off the way of grace and of growth, and discourage paths of sanctification which give glory to God. Let us remember that "a small step, in the midst of great human limitations, can be more pleasing to God than a life which appears outwardly in order, but moves through the day without confronting great difficulties". The practical pastoral care of ministers and of communities must not fail to embrace this reality. In every situation, when dealing with those who have difficulties in living God's law to the full, the invitation to pursue the via caritatis must be clearly heard. Fraternal charity is the first law of Christians (cf. Jn 15:12; Gal 5:14)" (my emphasis).

\section{Conclusion}

Fifty years on Humanae Vitae still shows us clearly how the truth, which the Church teaches remains truly prophetic. Even if for some, the encyclical has been the source of much confusion and even wounds, especially when its spirit was not completely understood, its teaching throughout the years has become more - not less - urgent. May we, as ministers in the Church and servants of the people of God, find the appropriate language for the essential teaching on the nature of the human being found in this encyclical to echo ever more strongly in the hearts of humanity.

\section{Bibliography}

Delicata N., The Family and the Dominant Technocratic Paradigm: Challenges in a Digital Culture, in: Strengthening Families, eds. J. Stala, J. Garmaz, Krakow 2016: Pontifical University of John Paul II in Krakow Press, pp. 223-250.

Delicata N., The Renewal of Moral Theology: From Confessing Sins to Forming Christians in the World, in: The Quest for Authenticity and Human Dignity: A Festschrift in Honour of Professor George Grima on his 70th 
birthday, eds. H. Scerri, E. Agius, Valletta, Malta 2015: Foundation for Theological Studies, pp. 135-153.

Pope Francis, Apostolic Exhortation Amoris Laetitia: On Love in the Family. March 19, 2016. http://w2.vatican.va/content/dam/francesco/ pdf/apost_exhortations/documents/papa-francesco_esortazioneap_20160319_amoris-laetitia_en.pdf (28.12.2018).

Pope Francis, Apostolic Exhortation Evangelii Gaudium: On the Proclamation of the Gospel in Today's World. November 24, 2013. http:// w2.vatican.va/content/francesco/en/apost_exhortations/documents/ papa-francesco_esortazione-ap_20131124_evangelii-gaudium.html (28.12.2018).

Pope Francis, Encyclical Laudato Si: On Care of Our Common Home. May 24, 2015. http://w2.vatican.va/content/francesco/en/encyclicals/ documents/papa-francesco_20150524_enciclica-laudato-si.html (28.12.2018).

Pope John Paul II, Apostolic Exhortation Familiaris Consortio: On the Christian Family in the Modern World. November 22, 1981. http:// w2.vatican.va/content/john-paul-ii/en/apost_exhortations/documents/ hf_jp-ii_exh_19811122_familiaris-consortio.html (28.12.2018).

Pope Paul VI, Encyclical Humanae Vitae: On the Regulation of Birth. July 25, 1968. https://w2.vatican.va/content/paul-vi/en/encyclicals/documents/ hf_p-vi_enc_25071968_humanae-vitae.html (28.12.2018).

Pope Paul VI, Encyclical Populorum Progressio: On the Development of Peoples. March 26, 1967. http://w2.vatican.va/content/paul-vi/en/ encyclicals/documents/hf_p-vi_enc_26031967_populorum.html (28.12.2018). 
